\title{
Transparency in port governance: setting a research agenda
}

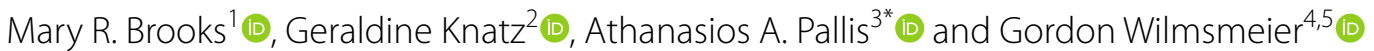

\section{${ }^{*}$ Correspondence:}

apallis@uoa.gr

${ }^{3}$ Department of Port

Management and Shipping,

National and Kapodistrian

University of Athens, Evripou

Campus, 34400 Athens,

Greece

Full list of author information is available at the end of the article

\begin{abstract}
This study examines the concept of transparency as practiced (or not) in ports. It explores the availability of information to the general public and port stakeholders through the ports' most public face-its website, studying public ports in North America, Europe, and Latin America and the Caribbean. This exploratory research centred on identifying the parameters that would be useful for the general public to have sufficient information to monitor, review and in many cases, participate in the decision-making processes carried out by the port authority, irrespective of whether or not laws mandate such disclosure. Fifty-one items were identified for the examination of each port's website, focusing primarily on four major categories: decision-making governance, port communications and accessibility, transparency in reporting and in port operational activities. Using nine items as proxies for the 51, the research reveals uneven levels of port transparency both regionally and by governance model. The study reveals a need for increasing and differentiating the existing levels and standards of transparency in the governance of the port industry, and for greater consistency between ports within and across regions. The study concludes with a research agenda for future research.
\end{abstract}

\section{Introduction}

Port policy reforms have been examined over the last three decades (see contributions in Brooks and Cullinane 2006; Brooks and Pallis 2012; Brooks et al. 2017) but with limited investigation into transparency of the decision-making process by public port authorities. The knowledge on what transparency actually entails and the relevant practices applied in the maritime and port sector is limited. This study explores the levels and standards of transparency in the governance of ports.

The aim is threefold. First, to develop a clear definition of transparency and its dimensions. Second, to provide information regarding the existing practices in world ports. Third, to set a research agenda towards a better understanding of current levels of port transparency as well as ways to further enhance it. Eighty-seven public ports in the Americas and Europe were surveyed, the specific port authority, the entity governing ports or the government departments involved in port policy-making.

Over the last several years, more and more countries have endorsed rules that require a minimum level of transparency in governing economic activities (Michener et al. author(s) and the source, provide a link to the Creative Commons licence, and indicate if changes were made. The images or other third party material in this article are included in the article's Creative Commons licence, unless indicated otherwise in a credit line to the material. If material is not included in the article's Creative Commons licence and your intended use is not permitted by statutory regulation or exceeds the permitted use, you will need to obtain permission directly from the copyright holder. To view a copy of this licence, visit http:// creativecommons.org/licenses/by/4.0/. 
2014). One example is the U.S. 'sunshine laws' that aim to ensure certain government activities are conducted in an open and ethical nature, and they apply to both federal and state government agencies and/or to business activities where the public domain retains a key role. These regulations require openness in decision-making meetings, records, votes, deliberations, and other official actions available for public observation, participation, and/or inspection, as well as government meetings to be held with sufficient advance notice and at times and places that are convenient and accessible to the public, with exceptions for emergency meetings. In Latin America, only Venezuela and Costa Rica have not legislated on access to information. Brazil was one of the last countries to join this movement for greater transparency (Michener et al. 2014). However, several countries have yet to endorse and apply relevant regulatory obligations and, as a result, both the practices of government agencies and businesses develop in an ad hoc basis. Governments in countries with a history of being 'corrupt' and non-transparent need to approach transparency not only as a matter of visibility of information, but as a tool to achieve concrete policy objectives and build public trust (Baena and Vieyra 2011; Molina and Vieyra 2012).

For the purposes of this research, a public port is defined as any port where there is an element of public ownership that requires stewardship; in addition to those ports where publicly-owned assets are managed by a public entity, we include in our definition of public ports, corporatized ports where the public assets may be the land but the management is by a non-profit or share capital corporation with some level of public ownership. Therefore, private ports on private property where all activities and assets are for profit (e.g. the British ports of Felixstowe and Southampton) are excluded from this research. Consequently, transparency in ports will vary across regions and governance models. Irrespective of whether transparency defined by the key indicators used in this study were undertaken by the port were imposed through legislation or voluntarily adopted, effective transparency includes a company's willingness to consistently communicate and make visible and verifiable information available to internal or external stakeholders (Kundeliene and Leitoniene 2015; Bushman et al. 2004).

The research questions adressed are three. Firstly, what is the definition and concept of transparency in the context of port governance? Secondly, what are current levels and differences of visibility of information in public ports? Finally, based on the findings of this research, the final question is, what are the needs for further research in the field of port governance?

Recognizing that there is little published research on transparency in ports, we undertake to explore transparency in ports initially by analyzing and defining the concept and dimensions of transparency in ports. This inludes identifying a set of practices used by public port authorities in different countries that would appear to promote good governance and enhance the democratic processes. The lack of background research and literature on port transparency makes it necessary to undertake this initial stage of research to lay a foundation for clearly defining transparency and identifying the scope of a research agenda.

This research explores the differences in the visibility of information available to the general public and port stakeholders through port websites. Using or searching a port website commonly is the first action taken by a member of the public or a port 
stakeholder to find information. The visibility of information and the ease with which it can be located is considered one dimension of a port's commitment to transparency.

By examining the current levels of transparency in ports in different countries, this article aims to contribute to showcasing and highlighting the differentiated use and approaches to transparency and, by doing so, to construct a research agenda towards the relevance and understanding of transparency and its role in 'good governance' of these critical infrastructures.

\section{Transparency in port governance}

The issue of transparency has been analysed only marginally by studies examining Port Authority (PA) communications in terms of disclosed contents. A content analysis of annual reports of 38 PAs by Parola et al. (2013) examined the innovativeness and potential determinants of the disclosed corporate communication. Notteboom et al (2015) evaluated the annual reports of the Port of Rotterdam Authority, investigating information disclosure as a tool for successfully managing the evolving interests of stakeholders and supporting the implementation of corporate strategy in the management of critical issues. These studies revealed the changing importance of topics reported over time; external pressures and internal key events have led to a shift from financial and governance issues towards broader community themes, like environment and safety/security.

In a more explicit manner, port transparency has been part of studies targeting the assessment of national port governance models. Verhoeven and Vanoutrive (2012) identified four port types using factor analysis on a database of 116 port authorities containing 72 variables. Corporate governance variables played a role in the allocation of ports to groupings by autonomy, port proactiveness, transparency in financial accounting, contracting out, and public versus private funding. In other words, they found four port types and concluded that governance matters. Examining port governance in Canada, Brooks (2017) questioned, among other topics, whether given the potential for private equity participation, Canadian Port Authorities (CPAs) meet the 'good governance' principles expected of Canadian publicly traded companies. Focusing on how competition is driving change in port governance, strategic decision-making and government policy in the US, Knatz (2017) addressed action taken by the Texas legislature due to finding a lack of transparency at the Port of Houston as part of 'fixing the governance' exercise. More than a decade earlier, Ubbels (2005) studied the Hamburg-Le Havre range in Europe, and advocated that the low levels of transparency and the differences in (national) port management styles are the two major institutional barriers to the creation of a level playing field in the European port industry. Given the competitive nature of the port industry, with almost all ports seeking to be industry leaders, the quality of governance must come into play.

Brooks and Pallis (2012) noted that 63 of 69 ports studied (69 of the 125 largest ports in the world) had a 'Board of Directors' (BoD) but what those BoDs did, how they were directed and what their priorities were, differed, calling this 'the myth of the perfect model.' It is common in state-owned or state-related entities, and, not least, personally experienced by the researchers, that political influence and/or connections might be critical for the work of a port's BoD. Besides, public control in such entities frequently translates to many prominent local politicians and former bureaucrats and few independent 
directors serving the respective Boards. In this context, politically connected BoD members might pursue other than expected goals (Menozzi and Vannoni 2014). They might prefer serving political alliances, in order to perpetuate their tenure on the board and keep themselves in the limelight. Following political masters (who appointed you) is the way towards reappointment or, in some cases, re-election. Other goals, like securing funding for the local community or pursuing a political mission, might be prioritised making the difference in a port's ability to compete.

Studies indicate that transparency issues come into play when discussing the effectiveness of port governance as well as decision-making by the entity assigned with the responsibility of managing the port. To our best knowledge no study in the port governance literature exists that has actually clearly defined transparency or compared practices in the port sector. As the variety of governance models increases (see the recap of trends in 24 different countries in Brooks et al. 2017), a detailed examination of the level(s) of transparency in place would help evaluate (a) whether any or all ports are today more transparent than in the past; and (b) whether different choices with respect to the interplay of the public and private sector in the governance of ports might affect transparency levels.

Port governance and reforms are frequently highly politicized processes affected by the institutional setting, i.e., the rules and norms of the economies within which they are embedded (Ng and Pallis 2010; Notteboom et al 2021). The levels of transparency of any entity like a PA-whether public, private, or a hybrid (features of both) - are frequently imposed by national legislation and regulatory mechanisms, which in turn are subject to the cultural dynamics of the political economy within which they are embedded. In Latin America, for example, this political economy is infused with cultural imprints, such as persistent military intervention, patronage networks and external intervention by powerful private or government forces, i.e., a context designed by a powerful set of actors unwilling to face up to the connected corruption (Brown and Cloke 2004). The transport sector in general and the port sector specifically would not be unaffected, both because of its vital role in the economy, and the magnitude of investments and accompanying financial operations. Due to the latter, transparency related to the governance, funding, and financing of transport infrastructure has been seen as important, by both scholars (O'Brien et al. 2019) and government initiatives examining corruption worldwide (i.e., Transparency International 2019). However, neither the relationship between transparency and the current institutional setting nor the role of path dependency might be linear; as Notteboom et al. (2013) advocated, a PA's routines might demonstrate the institutional plasticity to recombine and convert or reinterpret their institutional setting for their own objectives. Thus, different regions and countries were included in this study to understand the extent that cultural and institutional factors might be decisive for the levels of port transparency, and good governance.

Seeking to capture the influence of national institutions and port specific characteristics in sustainability reporting, Santos et al (2016) used content analysis to analyse the extent and content of one dimension of transparency (i.e., corporate sustainability information) disclosed in the websites of 186 European seaports. Applying institutional theory, the scholars suggest that institutional context and institutional pressures, exerted by society and by cities where ports are located, are important to justify sustainability 
communication by ports (i.e., coercive, normative and mimetic pressures can explain the variety of the performance observed), and suggested that there is still much work to be done by ports in reporting, and further research to be conducted as regards communication of ports with stakeholders.

\section{Dimensions of transparency}

Transparency is a multidimensional concept that cannot be thoroughly explored by a single study. It is generally associated with information flows, formal disclosure policies, and publication approaches, as well as discussions and meetings with stakeholders. Communication protocols are also relevant; for example, has the port kept pace with newer ways to communicate, like websites and social media, or are they still publishing notices in newspapers that a large segment of the population no longer reads?

The etymological meaning of transparency refers to 'seeing through' or making visible, which is then commonly defined as the principle of enabling stakeholders to gain information about the operations and structures of a given entity. Transparency is often considered synonymous with openness/disclosure (cf. Finel and Lord 1999; Heald 2006; Hood 2006), and facilitating trust (Valentinov et al. 2019; Hultman and Axelsson 2007; Schnackenberg and Tomlinson 2016). Despite a wide use of the concept of transparency, its definition(s) remain(s) somewhat opaque, vague and volatile (Williams 2005; Michener and Bersch 2013; Albu and Flyverboom 2016). Thus, a detailed examination of the concept is used to define the limits of the current research and future research gaps and needs.

Michener and Bersch (2013) define two dimensions of transparency, visibility and inferability. Visibility refers to the degree to which information is complete and easily located (visible). Inferability concerns the extent to which the information, in its form and content, can be used to draw accurate conclusions. These dimensions are interdependent with their combination creating transparency at it base level. An asymmetry is embodied in this definition: "the qualities of visibility are intrinsic to the information, whereas inferability is also contingent on the receptive capacity of the intended audience hence inferability depends on the target audience" (Michener and Bersch 2013: 238). Albu and Flyverboom (2016) describe two other approaches, verifiability and performativity. Verifiability considers a "view of transparency as a matter of information disclosure, a focus on the quality and quantity of information that permits to fully observe organizational action, and a means of solving organizational and societal problems by improving the effectiveness and quality of transparency" (Albu and Flyverboom 2016: 289). Performativity sees transparency as a process which induces social action; a focus on the conflicts, tensions, and negotiations that can arise as a result of the dynamics specific to acts of making things visible in organizations; and an understanding that transparency enactment creates unintended consequences and leads to the management of visibilities in organizational settings (Albu and Flyverboom 2016).

Based on this, a nested concept of the dimensions of transparency emerges (Fig. 1), which enables us to delineate our current research as being focused primarily on visibility.

Within the context of verifiability the concept of information disclosure or visibility stands in the centre of the discussion (Eijffinger and Geraats 2006; Wehmeier and Raaz 


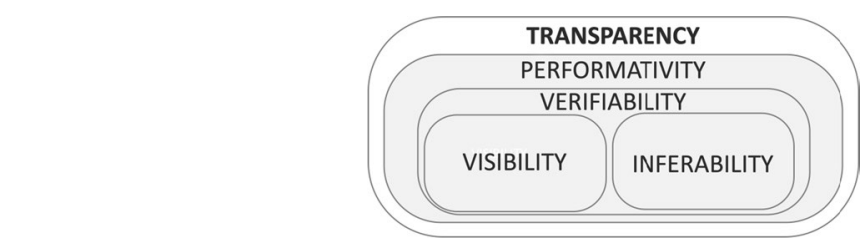

Fig. 1 Nested dimensions of transparency. Source: Authors' own elaboration

2012; Berglund 2014). In this manner, transparency is limited to information disclosure via a linear communication model (Fenster 2015) with the visibility of information being a basic condition. However, information to be considered visible must be complete and found with relative ease.

The term of visibility needs to be distinguished from the term public. Public information is not automatically visible. Michener and Bersch (2013) differentiate between 'active' and 'passive' transparency (that is, visibility). The first refers to information that is voluntarily or obligatorily rendered visible, while the second describes the possibility that information can be rendered visible through a specific request process. Consequently, public information only becomes transparent, if it is made visible, but not by being kept in a repository or by simply being defined as 'public,'but through a freedom of information (FOI) act or law. This last point is important because many organisations hide key reports that should be visible but require FOI action to make visible.

A further characteristic that defines transparency through visibility is the ease of locating specific information; in the case of this research, this is the ease of locating specific information within a port's website. Consequently, the basic condition of transparencythe visibility of information-is defined by its completeness and the likelihood that it will be found.

Beyond the matter of accessibility itself, a characteristic of verifiability is the degree of completeness of information. By way of example, a summarized unaudited financial report makes the financial results of a port visible, but does not reveal a complete picture. Rather than considering a priori that accessibility equals to transparency, it is worth researching whether the disclosed information is complete or not.

Over time transparency has evolved from the motive of visibility of information to explicit demands for its inferability. This follows the expectations that the information provided by the organization is not just visible, but also valid and truthful (Bernstein 2012; Schnackenberg and Tomlinson 2016). The interest in inferable data not just originates from the acknowledgment that raw data frequently allows for greater verifiability and is more detailed, yet false transparency and unintelligible disclosures remain persistent problems (Michener and Bersch 2013). Inferability is the extent to which the information at hand can be used to draw accurate inference-both about visible information and information we do not know, and is about the quality of the information or data. It increases via data disaggregation (availability of raw data), verifiability (verified by a third party) and simplification, i.e. it is 'understandable' data (Michener and Bersch 2013).

Simplified heuristics make information more accessible. Simplification of data, thus, needs to be adequate. Hood (2007) differentiated between indirect transparency (transparency understood by experts) and direct transparency, which reaches the 
wider public. Expecting information to speak to every stakeholder is idealistic. Generalizing information might result in less transparency as it limits accuracy.

This paper follows Michener and Bersch (2013) arguing that information to be acknowledged as transparent must be, to a certain extent, visible (complete and findable) and inferable, incorporating some element(s) of disaggregation, verification or simplification. While visibility's attributes (completeness and findability) are both necessary, inferability's attributes (disaggregation, verification, and simplification) are substitutable and adaptable to the intended audience. Visibility is the primary focus of this research.

Transparency builds on the notion that information matters and that information can empower and improve. The availability of specific information - on a voluntary or mandatory basis-to all the actors, principals, agents and stakeholders enables recipients to hold a company (in this case the entity responsible for managing the port) accountable by comparing the company's stated goals to its actual performance and the performance of others. Further, transparency can support a company's performance as the access to information allows recipients to compare results in the same market (Hess 2012).

Based on this notion, we argue that transparency is connected with other concepts. Figure 2 graphically illustrates the links between transparency, accountability, responsibility, and focus on performance improvement.

There is a lack of a conceptual consensus regarding what exactly constitutes 'transparency' and its link to other concepts. By way of example, transparency has at times been used as a synonym for accountability (Christensen and Cornelissen 2015). Craft and Heim (2008) argues that transparency is a key element in the construction of organizational accountability, but a different concept. Craig et al. (2016) consider accountability as an aspect of transparency. This paper follows Craft and Heim (2008) and argues that accountability is a result of transparency that can be verified, and relates to the generation of trust with stakeholders. Consequently, accountability originates from an institution's or company's responsibility towards its stakeholders. This responsibility is linked to the considerations that stakeholder empowerment is one way of seeking and developing improvements and that the consequently altered nature of existing power relationships between actors contributes to a managerial focus on better outcomes.

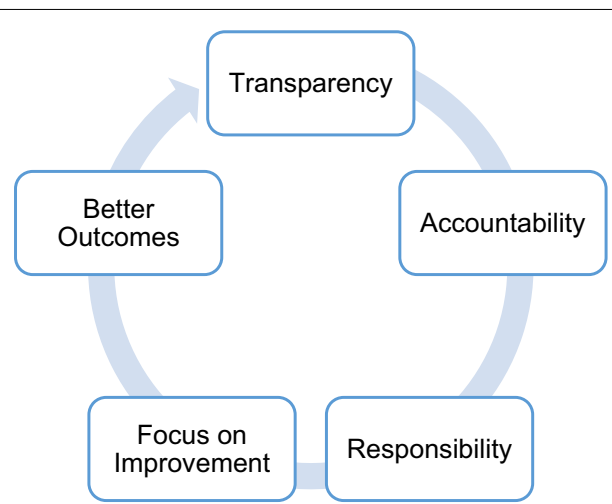

Fig. 2 Links between transparency, accountability, responsibility, and performance. Source: Authors' own elaboration 


\section{Methodology}

In order to examine these concepts as they relate to port governance, 51 factors in two categories were identified for assessing the visibility of a port's decision-making governance, and its communications and operations.

Eighty-seven ports were surveyed, 23 in the United States (US), 17 in Canada, 21 in Latin America and the Caribbean and 26 in Europe (Table 1). In the United States, public ports, both large and small, were selected from each of four coastlines (Pacific; Atlantic, Gulf; Great Lakes). This ensured coverage of all areas of the country, providing an opportunity to examine regional differences within the U.S. In Canada, all Canada Port Authorities (CPAs) were examined; these ports are 'corporatised federal agencies' under the Canada Marine Act 1998 and responsible for all of the international container traffic and the majority of international bulk traffic. In Europe, the sample includes the major port in each of the 21 European Union member countries plus any other port listed in the top- 15 container ports in terms of throughput using 2018 data. In Latin America and the Caribbean, the sample includes the major ports in 12 selected countries.

This study concentrates on the transparency issues associated with public ports only. Public ports have some element of public ownership and thus the port has a fiduciary responsibility, which is served by transparency and disclosure, to the public (taxpayers and citizens). The same is not true for private ports, whose fiduciary responsibility is to owners and shareholders only. The exclusion of private ports therefore does not compromise the results.

Ports in different parts of the world have different governance structures and different mandates for public access and disclosure. In the search for possible intra-regional disparities on the differences in transparency due to cultural and governance approaches, the countries in North America are presented separately. This exploratory investigation

Table 1 Examined ports

\begin{tabular}{|c|c|c|c|c|c|}
\hline Region & $\mathbf{n}$ & Sub-region & n & Port Governance & n \\
\hline \multirow[t]{3}{*}{ Canada } & 17 & $\begin{array}{l}\text { Eastern Canada and St. } \\
\text { Lawrence River }\end{array}$ & 9 & Corporatised public PA & 17 \\
\hline & & Western Canada & 4 & & \\
\hline & & Great Lakes Canada & 4 & & \\
\hline \multirow[t]{5}{*}{ Europe } & 26 & Mediterranean & 11 & Public Port Authority & 15 \\
\hline & & North Europe & 8 & Corporatised public PA & 5 \\
\hline & & Baltic & 5 & Listed company public sector majority & 3 \\
\hline & & Black Sea & 2 & Listed company / private majority & 1 \\
\hline & & & & National Port Authority & 2 \\
\hline \multirow{3}{*}{$\begin{array}{l}\text { Latin America and } \\
\text { Caribbean }\end{array}$} & 21 & South America & 12 & Public Port Authority & 14 \\
\hline & & Central America & 6 & State (national) Port Authority & 7 \\
\hline & & Caribbean & 3 & & \\
\hline \multirow[t]{4}{*}{ USA } & 23 & Atlantic & 8 & Public Port Authority & 23 \\
\hline & & Pacific & 6 & & \\
\hline & & Gulf & 5 & & \\
\hline & & Great Lakes USA & 4 & & \\
\hline Total & 87 & & & & \\
\hline
\end{tabular}

While there were 87 ports in the sample, five ports did not have a governance that included a Board of Directors 
centered on identifying the parameters that would be useful for the general public to have sufficient information to monitor, review and, in many cases, participate in the decision-making process carried out by the port authority, irrespective of whether or not laws mandate such disclosure. Research data was collected by a systematic review of each port's website. Where a port may be part of a larger government authority (an office within a state department of transportation in the case of some U.S. ports), the website of the higher government authority was also searched. Thus, the methodology focuses on the visibility dimension of transparency.

As this research focuses on active visibility, in all four categories data were recorded on each of the 51 items in Table 2 as yes, when the information was found on the port website or in a downloadable report on that website, and could be downloaded by anyone. A no meant the data was not available or, at least, not found within one hour of searching the site or any downloadable report. There may be cases where the data are publicly available and may even be on the website but was not found by the investigators within that one-hour time limit. While this may mean that 'yes' may be understated, difficulty in finding information is one indicator of poor visibility.

Finally, to clarify this approach, the authors only looked at one small aspect of port governance, believing that the governance of public ports should be held to the same standards as other governmental agencies. Given the sheer number of data items in Table 2, the limitation of the research to ports was intentional, and maritime shipping governance, while interesting, is not the subject of this paper.

\section{Analysis and discussion}

\section{Identifying proxies for transparency}

The multidimensionality of 51 items of transparency was too great, thus the researchers identified the most promising indicators as proxies for transparency, returning nine proxies (as noted in Fig. 3) for discussion of the findings.

The decision-making governance category included items that would allow stakeholders and community members seeking to identify any potential conflicts of interest held by Board Members. It is considered that a minimum level of information on the Board members should include some biographic information. In order to identify conflicts of interest, the proxy chosen was the presence of biographies of Board Members either on website or in the annual report (Proxy 1). Furthermore, information on Board committees was often very limited and the ability to assess processes for decision-making constrained.

Considering decision-making governance, in some jurisdictions, the Board and/or Annual Meetings are primary accountability mechanisms, but in others jurisdictions this is simply not true. By way of example, we found that Board Meetings are the primary mechanism for accountability to the public in the U.S., while in Canada, the Annual Meeting incentivises Board accountability; in some cases neither is made actively visible (e.g., Puerto Rico). Given this variation, these two categories were collapsed for reporting purposes and two items were chosen as proxies-Annual Meeting (AM) and/or the Board Meeting (BM) are open to the public (Proxy 2), and Board/Annual Meeting minutes are published (Proxy 3). 
Table 2 Items included in data set for each port (1)

\begin{tabular}{|c|c|}
\hline Item no & Item description \\
\hline \multicolumn{2}{|c|}{ Category 1A: Decision-making governance—visibility of conflicts of interest } \\
\hline 1 & Website/AR provides bio of BoD members (Proxy 1) \\
\hline 2 & Website/AR specifies Board Member qualifications \\
\hline 3 & Website/AR specifies of organisations represented \\
\hline 4 & $\begin{array}{l}\text { Website/AR provides information on other Board } \\
\text { appointments held by each Member }\end{array}$ \\
\hline 5 & Executive officers salaries are reported \\
\hline 6 & Board committees are identified \\
\hline 7 & Board committee members are listed \\
\hline 8 & There is a Governance committee \\
\hline 9 & There is a (Finance and) Audit committee \\
\hline 10 & There is/are (a) Standing advice committee(s) \\
\hline 11 & There is an Ad hoc or project Committee \\
\hline 12 & Ethics hotline (on web site) \\
\hline \multicolumn{2}{|c|}{ Category 1B: Decision-making governance_-information/openness re: annual meeting and/or board meetings } \\
\hline 13 & Available via webcast (AM) \\
\hline 14 & Open to the public (AM) (Proxy 2a) \\
\hline 15 & By invitation only (AM) \\
\hline 16 & Prior notice of meetings is given (AM) \\
\hline 17 & Agenda is posted in advance (AM) \\
\hline 18 & Agenda is publicly available (AM) \\
\hline 19 & List of meeting attendance is published (AM) \\
\hline 20 & Minutes are published (AM) (Proxy 3a) \\
\hline 21 & Available via webcast (BM) \\
\hline 22 & Open to the public (BM) (Proxy 2b) \\
\hline 23 & By invitation only (BM) \\
\hline 24 & Prior notice of meetings is given (BM) \\
\hline 25 & Agenda is posted in advance (BM) \\
\hline 26 & Agenda is publicly available (BM) \\
\hline 27 & List of meeting attendance is published (BM) \\
\hline 28 & Minutes are published (BM) (Proxy $3 b$ ) \\
\hline \multicolumn{2}{|c|}{ Category 2: Port communications and information accessibility } \\
\hline 29 & Do public community/stakeholder meetings exist? \\
\hline 30 & $\begin{array}{l}\text { Website has a community or stakeholder link (Proxy } \\
\text { 4) }\end{array}$ \\
\hline 31 & Website has a stakeholder report \\
\hline 32 & Website/AR reports community investment \\
\hline 33 & $\begin{array}{l}\text { Email/ phone of executive staff available on website } \\
\text { (Proxy 5) }\end{array}$ \\
\hline 34 & $\begin{array}{l}\text { Only communication personnel email/phone available } \\
\text { on website }\end{array}$ \\
\hline 35 & Form required to be submitted \\
\hline 36 & Facebook \\
\hline 37 & Twitter \\
\hline 38 & Linkedln \\
\hline 39 & Published privacy policy \\
\hline \multicolumn{2}{|c|}{ Category 3: Transparency in reporting —availability of port-generated reports } \\
\hline 40 & AR publicly available on the website (Proxy 6) \\
\hline \multirow[t]{2}{*}{41} & AR publicly available upon request \\
\hline & Financial reports publicly available on the website \\
\hline
\end{tabular}


Table 2 (continued)

\begin{tabular}{ll}
\hline Item no & Item description \\
\hline 42 & $\begin{array}{l}\text { Audited financial reports publicly available on the } \\
\text { website (Proxy 7) }\end{array}$ \\
43 & Financial reports publicly available upon request \\
44 & Budget reports publicly available on the website \\
45 & $\begin{array}{l}\text { Corporate social responsibility (CRS) and/or environ- } \\
\text { mental, sustainability and governance (ESG) reports } \\
\text { publicly available on the website (Proxy 8) }\end{array}$ \\
46 & $\begin{array}{l}\text { Master plans public consultation at inception/amend- } \\
\text { ment }\end{array}$ \\
47 & Master plans publicly available on the website \\
48 & $\begin{array}{l}\text { Multi-language materials are available (reports/press } \\
\text { releases) }\end{array}$ \\
Category 4: Transparency in operations - availability of information on port operations \\
49
\end{tabular}

AR, annual report; AM, annual meeting; BM, board meeting

Proxies chosen in "Analysis and discussion" section of this article (Fig. 2) are bolded

A public dashboard is an online link where a port may share data about its operational activities; this may include webcams, indicators of gate wait times, vessel berth times, and any other real-time information of its choosing

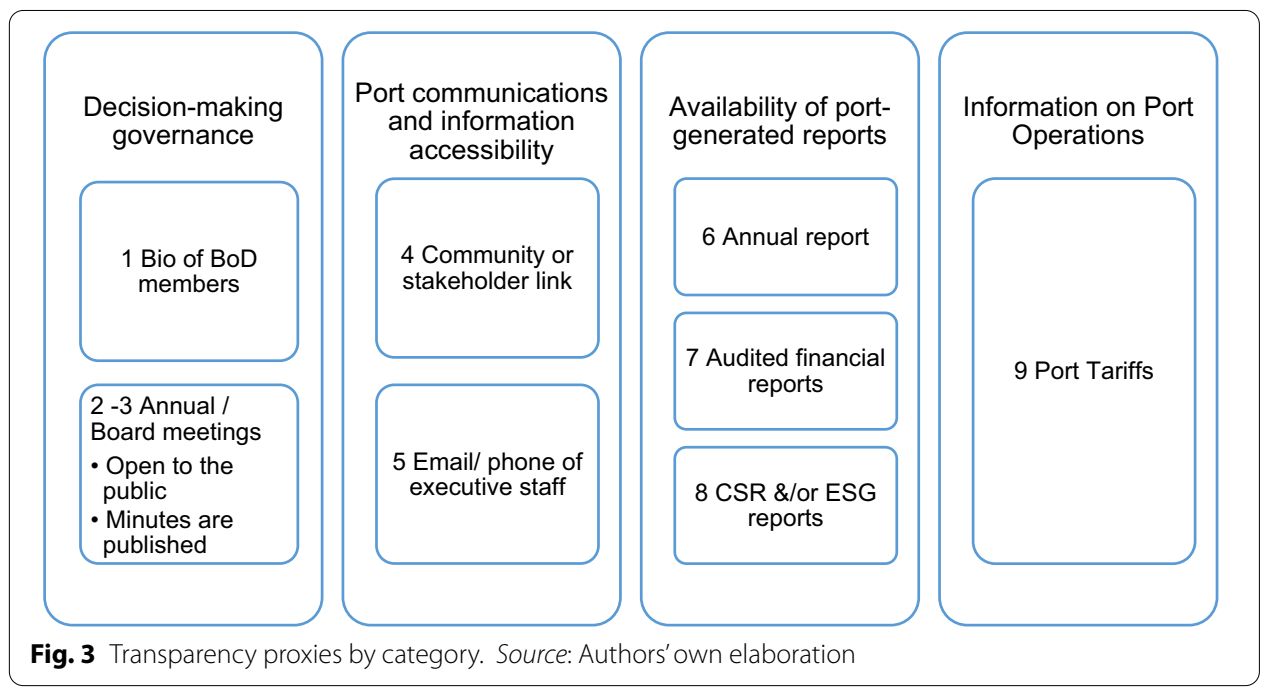

The primary purpose of the items chosen for the port communications and information accessibility category was to understand how and what ports were communicating to their audiences. The availability of community or stakeholder link(s) on the website (Proxy 4) was chosen as a proxy for existing strong community relations. The items in this category also included visibility/transparency on the appropriate person in the organization to deal with requests from outside. Here the proxy chosen was contact information for key executives and staff (Proxy 5). As for transparency in reporting, the availability of port-generated reports for reading/downloading, we identified three proxies: annual reports (Proxy 6), audited financial statements (Proxy 7), and CSR and/or ESG reports (Proxy 8). Finally, for transparency in port operational activities, we 
identified the availability of port tariffs (Proxy 9) as relevant. Port tariffs contain rates and charges but also operational requirements. Often, especially in larger container ports, a tariff may be superseded by a lease or concession agreement. At these ports, a more relevant proxy might be a dashboard with real-time operational data. Thus, these nine may not be the right proxies or the right number of proxies, but that will be discussed later.

\section{Study results}

The research reveals different levels and types of port transparency across the four regions, and identifies areas where there is a need for further improvements in that transparency as this investigation was limited primarily to the dimension of visibility. Within each region, transparency levels in decision-making governance, the reporting of these decisions, and the consequent port activities were found to be inconsistent. Reporting on relations with stakeholders and public consultations are often irregular and therefore unreliable to the intended audience. Inconsistency is the primary finding. Comparing these results with indications in few relevant studies of the past demonstrates that, in general, transparency has improved over time but, for many ports, there is a considerable distance to go and further improvements are possible.

The relatively low levels of port transparency are underlined when the port transparency proxies are reported. Table 3 provides this summary, with the indicators also demonstrating that ports in different countries and/or regions of the world have endorsed different information disclosure practices, decision-making procedures, and communication and accessibility strategies. Similar are the findings when comparing transparency levels on the basis of the different models of port governance (Table 4). A detailed regional and governance model analysis on all 51 items can be found in a technical report by the Brooks et al. (2020).

At a practical level, these findings reveal a need for increasing the existing levels and standards of transparency in the governance of the port industry. The analysis also provides details on those aspects where port transparency might be considered as satisfactory. Yet this exploratory study has also revealed a number of questions that need to be further studied in order to facilitate port authorities, and relevant decision makers at national or regional level, to proceed to implement corrections to the existing policies and actions.

\section{Discussion}

What is transparency in the context of ports? The conducted research emphasizes that the need to define port transparency is not only conceptual. Some ports include statements of policies on transparency on the website. A search of the web site of Prince Rupert in Canada, for example, turns up the Access to Information requests received and addressed when the search is on the word 'transparency'. For Barcelona in Spain, the searcher will find information on the legislation governing the entity responsible for the governance of the port, its organizational structures, procedures and activities, as well as economic information (annual results and executed contracts). Elsewhere, ports note how they comply with disclosure legislation, whether or not the page is labelled as a transparency site. For example, the ports of Genoa/Savona and Gioa Tauro in Italy 


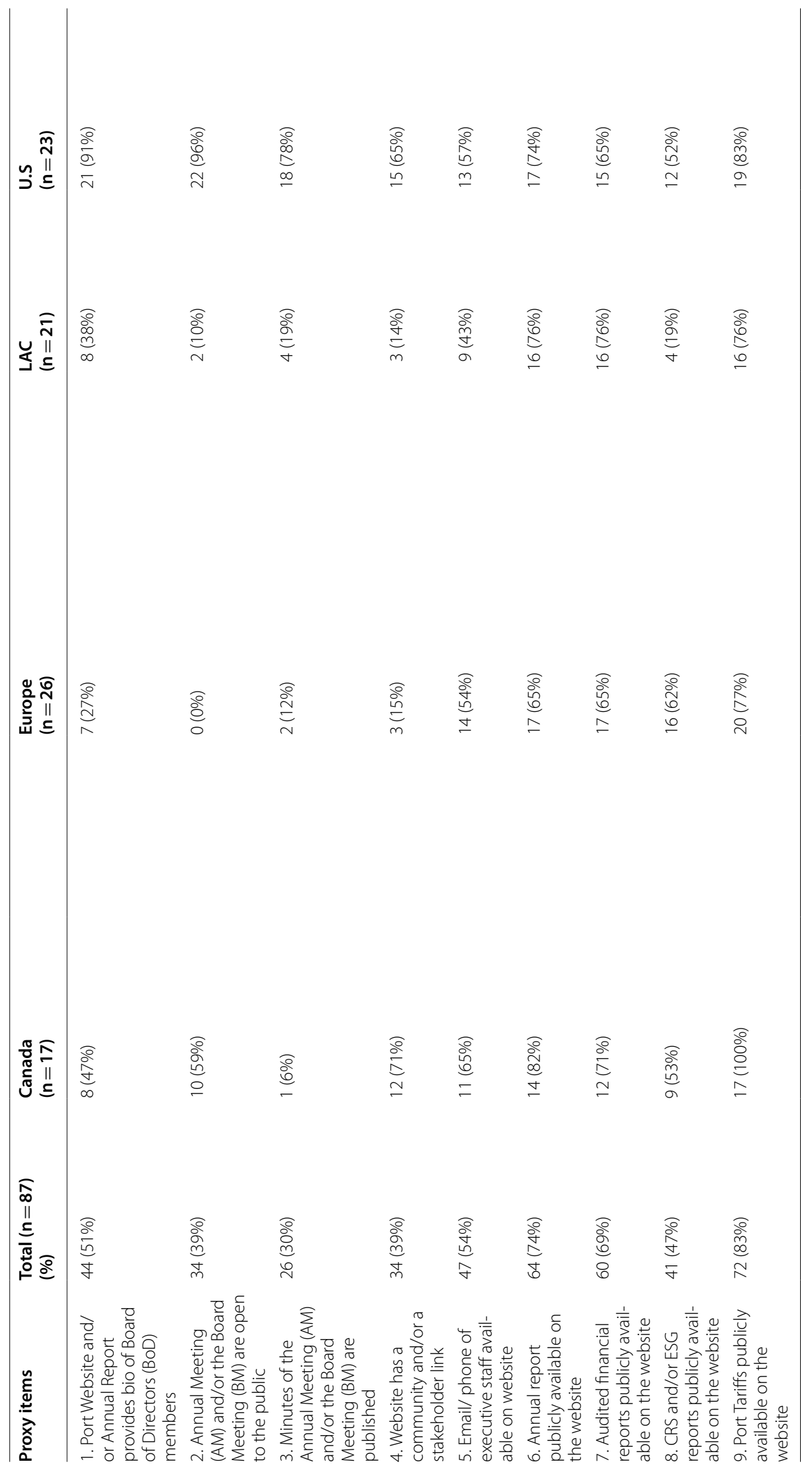


Table 4 Key port transparency indicators by governance model

\begin{tabular}{|c|c|c|c|c|c|c|}
\hline Proxy items & $\begin{array}{l}\text { Total }(\mathbf{n}=87) \\
(\%)\end{array}$ & $A(n=52)$ & $\begin{array}{l}B \\
(n=22)\end{array}$ & $\begin{array}{l}C \\
(n=3)\end{array}$ & $\begin{array}{l}D \\
(n=1)\end{array}$ & $\begin{array}{l}E \\
(n=9)\end{array}$ \\
\hline $\begin{array}{l}\text { 1. Port Website and/or Annual Report } \\
\text { provides bio of Board of Directors (BoD) } \\
\text { members }\end{array}$ & 44 (51\%) & 27 (52\%) & $10(45 \%)$ & $2(67 \%)$ & $1(100 \%)$ & $4(44 \%)$ \\
\hline $\begin{array}{l}\text { 2. Annual Meeting (AM) and/or the } \\
\text { Board Meeting (BM) are open to the } \\
\text { public }\end{array}$ & 34 (39\%) & $22(42 \%)$ & $10(45 \%)$ & $0(0 \%)$ & $0(0 \%)$ & $2(22 \%)$ \\
\hline $\begin{array}{l}\text { 3. Minutes of the Annual Meeting (AM) } \\
\text { and/or the Board Meeting (BM) are } \\
\text { published }\end{array}$ & $26(30 \%)$ & $20(38 \%)$ & $1(5 \%)$ & $2(67 \%)$ & $1(100 \%)$ & $2(22 \%)$ \\
\hline $\begin{array}{l}\text { 4. Website has a community and/or a } \\
\text { stakeholder link }\end{array}$ & 34 (39\%) & 19 (37\%) & $13(59 \%)$ & $0(0 \%)$ & $0(0 \%)$ & $2(22 \%)$ \\
\hline $\begin{array}{l}\text { 5. Email/ phone of executive staff avail- } \\
\text { able on website }\end{array}$ & 47 (54\%) & $29(56 \%)$ & 13 (59\%) & $2(67 \%)$ & $0(0 \%)$ & $3(33 \%)$ \\
\hline $\begin{array}{l}\text { 6. Annual report publicly available on } \\
\text { the website }\end{array}$ & 64 (74\%) & 39 (75\%) & 18 (82\%) & $3(100 \%)$ & 1 (100\%) & $3(33 \%)$ \\
\hline $\begin{array}{l}\text { 7. Audited financial reports publicly } \\
\text { available on the website }\end{array}$ & 60 (69\%) & 35 (67\%) & $16(73 \%)$ & $3(100 \%)$ & 1 (100\%) & $5(56 \%)$ \\
\hline $\begin{array}{l}\text { 8. CRS and/or ESG reports publicly avail- } \\
\text { able on the website }\end{array}$ & 41 (47\%) & 25 (48\%) & 13 (59\%) & $2(67 \%)$ & 1 (100\%) & $0(0 \%)$ \\
\hline $\begin{array}{l}\text { 9. Port Tariffs publicly available on the } \\
\text { website }\end{array}$ & 72 (83\%) & 42 (81\%) & 22 (100\%) & $2(67 \%)$ & 1 (100\%) & $5(56 \%)$ \\
\hline
\end{tabular}

Models of port governance: $\mathrm{A}=$ Public Port Authority $(\mathrm{PA}) ; \mathrm{B}=$ Corporatized Public $\mathrm{PA} ; \mathrm{C}=$ Listed company- public majority; $\mathrm{D}=$ Listed company- private majority; $\mathrm{E}=$ National level Authority

maintain transparency sections at their website, but these report bureaucratic administrative procedures, such as appointment of the president and executives of the port managing entity, procurement practices, expenses made and other financial issues. In the case of Chile, the websites of the local PA's are structured very similarly and include a specific 'transparency' section, which in all cases present the user a clearly structured collection of relevant information (annual reports, legal framework, detailed salaries, organisation structure and responsibilities). While the word 'transparency' may not appear on the web site, a number of ports in Canada have details on how directors are appointed; on the other hand, the process itself is not transparent and biographies of those chosen are not available. In summary, some ports disclose a significant amount of information and very specific details on particular issues, yet very little on information that may be sought by the local community. They all see 'transparency' differently, and so a common approach would be beneficial to the port management community, regulators and port stakeholders in general.

Based on Fig. 1, a basic condition is the visibility of the information in terms of quantity and quality. In publicly accountable organisations, it has to be available-accessibility also becomes important-for the general public to assess the when, how and why certain decisions are made, and to allow the stakeholders to participate in that review/ oversight process that leads to the accountability of directors and management, and ultimately responsibility by them for outcomes as noted in Fig. 2.

What information is useful? The information has to be timely (available with sufficient time before a public meeting for a stakeholder to have time to read and digest the information); it has to be recent; it has to be understandable (Hood 2007), including availability in the languages used by that public to which the organization is accountable; 
and it has to be an accurate representation of what that organisation is accountable for, e.g., complete reports are required; abstracts or summaries are therefore not transparent (Gupta 2008).

When is transparency important? Transparency is a concept that applies to the various stages of a decision-making process (Fig. 4): from the conceptualization $\left(t_{0}\right)$ to the initiation of port development, operation and management strategies $\left(t_{1}\right)$, the planning $\left(t_{2}\right)$ and detail of the decided actions (i.e., business plans, master plans, port works, and governance resolutions) $\left(t_{3}\right)$, and then during the phases of implementation $\left(t_{4}\right)$, operation $\left(t_{5}\right)$ and evaluation of the produced outcomes $\left(t_{6}, t_{7}\right)$ that could result in a restart of port reform (see Brooks and Pallis 2008). The levels of transparency in each of these stages define the involvement and contribution of service providers, users, and stakeholders, determining the effectiveness of the decisions taken, which Albu and Flyverboom (2016) refer to as performativity. With transparency having several components, i.e., governance/decision-making transparency, financial disclosure, and performance transparency, the availability of information at all stages of the process is alleged to be a key determinant of the efficiency of resource allocation decisions (Bushman et al. 2004). When organizations are opaque and their interests are secret, decision-making distorts efficiency.

Transparency for whom? The 'for whom' is key to what decision-making transparency refers to, whether the model is a private or corporatized port or a public port. In all cases, the governance model must balance the diverse expectations of shareholders (or government, private sector) and those of other stakeholders (e.g., general public), and the port community (including users, e.g., cargo interests, shipping companies and services providers such as terminal operators, nautical services, and landside operations). The governance model will determine if information is merely intended to inform or if it has both inform and involve roles to play for some, or all of these actors, while transparency would imply that both informing and involving is taking place at most stages of the decision-making process.

Who serves on the Board, and how they are appointed/nominated or elected is critical to decision-making transparency. The Board is to provide oversight of management

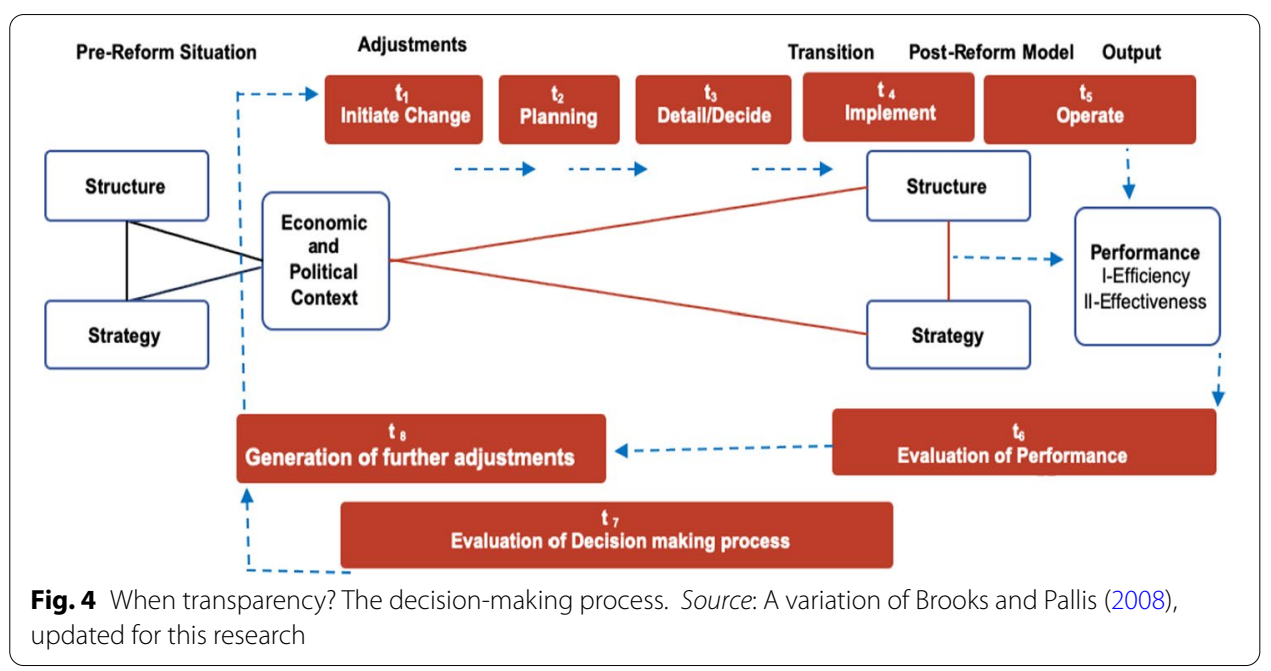


and 'good stewardship' of the assets of the organisation. In the private-sector, the Board is 'confirmed' by shareholders at the Annual Meeting and during its 'tenure' it serves to ensure that shareholders' interests are served. Shareholders scrutinize that the corporatised port's strategy is executed as part of the process, review the performance of the port, confirm the Board of Directors, and appoint the financial auditors. For ports that follow a public port model only, like U.S. ports, the port's management is mandated to act in the best interests of those who appoint management, be they politicians or local councils. Boards are responsible to those who appoint or elect them. The challenge is that in 'hybrid' models (those that feature selected elements of both public and private models), the reporting structure may not be clear, as the role of shareholder (private) or citizen/taxpayer (public) may not be adequately articulated in the governing legislation, regulations, or by-laws.

\section{Contribution to scholarly discipline: a research agenda}

In addition to developing a differentiated understanding of what transparency is-a nested concept of visibility, inferability, verifiability and performativity, this research has explored the state of visibility in the port sector, using a framework of 51 items in four categories. Further research is needed with respect to both the current levels of transparency and the observed variance in the 87 ports examined. We propose six streams for future research.

First, future research could identify the key parameters of port transparency, and develop a definition for each. The researchers embarked on a study of port transparency having proposed a number of different indicators and proxies for port transparency that are consistent with the overarching need for information that is useful, relevant, accessible, timely, and accurate/complete in reporting. This exploratory study, for example, revealed that reporting to stakeholders is inconsistent across ports. Some ports provide a colourful, graphic brochure or report on what they are doing, in general, with little detail on internal management decision-making; others have thorough reports that would meet the tests imposed by securities regulators on publicly-traded companies. Some ports provide minimalist financial statements, while others are detailed and complete with the unqualified auditor's opinion letter. Some ports, regrettably, limit their reports to only a few pages that do not even contain the detail required under the applicable legislation. While legislation in each country will have minimal requirements to be met, there are some general indicators of port transparency that can be compared across countries and it is important to both validate that the indicators proposed in this exploratory study meet a minimum of expectations for port governance researchers, governments to whom they report, and are useful to ports in meeting their accountability obligations. From this research, it will become clear if the nine proxies used in Fig. 3 are the correct proxies that should be used in future port governance research, and in developing a port transparency index.

A second area of research is to understand if there are specific dimensions that are crucial yet underestimated or not included. Ports that engage both users and their port community through a dashboard are to be lauded for transparency of activities (as opposed to governance and decision-making). There are many types of public dashboards; they are a relevant means of community engagement and customer service. 
There is plenty of scope for research into the types of public engagement, the success of particular dashboard models, and other approaches to engagement with community. For example, further research needs to be done to examine whether the port use of social media is replacing other ways ports used to engage with the public such as through community advisory committees. Are ports using social media as a one-way channel to push information they choose out to the public or are they also responding to inquiries and questions via social media? How social media may be used for any required public notification for environmental reporting is also an avenue for future research.

While the study looked at one small aspect of port governance, there are many additional dimensions of port governance and transparency-including the interactions between ports and interest groups, the media, and the like-that remaianed untouched but could be a future extension of this research. We believe that the governance of public ports should be held to the same standards as other governmental agencies, departments and state-owned enterprises, which rely on either publicly owned physical assets or are funded by public monies. This research sets a foundation that could be used to examine a broader array of public enterprises.

A third area for examination is that of compliance, be it obligatory or voluntary, and whether there are cultural norms that play a role. As noted by Hofstede (1980), cultural norms influence not only management decision-making but government regulation. Here, country- or region-level studies would be most useful, as governments make decisions about whether compliance should be monitored and whether compliance must be enforced. In some cases, transparency becomes part of compliance efforts. In others, port-managing entities may choose voluntary adoption, and this governance practice would be endorsed and then disclosed, i.e., incorporated into the Annual Report. Studying disclosure in the Annual Reports would allow for comparison of legislated requirements to what the Annual Reports actually contain. Exploring patterns of voluntary/mandatory adoption against cultural norms might reveal suitable governance patterns for known cultural biases. Furthermore, there may be new, post-pandemic cultural norms; for example, webcasting of meetings may grow in acceptability or practice to protect the vulnerable populations.

A fourth stream of future research would build on the first stream, and develop a gap analysis. Once the port transparency indicators are validated, expectations of various groups of port stakeholders could be identified, and a study conducted on the importance different stakeholder groups place on them and how they rate the performance of various ports on those indicators. For example, if a port is mandated to provide specific, differentiated data to its stakeholders, is that the data stakeholders want? Sometimes it becomes apparent that what is reported is not what is relevant to interested parties. In a recent eempirical study on such expectations, Brooks et al. (2021) revealed that on specific issues (i.e. the openness of decision-making meetings) stakeholders expectations are differing by region but there are no regional differences for other issues (such as the importance of information visibility for assessment of conflict of interest or other types of port supplied information). With port communication of Annual Reports and various stakeholder reports being inconsistent, ports wanting to improve stakeholder relations would do well to examine whether they are transparent in the way stakeholders they target deem importance. 
Fifth, the detailing of best practices through further case studies would be useful to ports wishing to improve their governance transparency. Survey results indicated notable examples that could serve as best practice examples. During the review of the Port of Oakland, a chat box opened with an inquiry asking if help was needed. This could be particularly useful if a port does not have a search engine on its home page. Several ports had a translation tab on their home page so the entire site could be translated into multiple languages with one click. Best practice examples would provide a service to ports interested in improving their transparency.

Finally, we excluded from the analysis the fully privatized ports, i.e., those ports where privatisation has gone as far as privately owned port land (on different privatisation scale, see: Brooks and Pallis 2012). The grounds for this exclusion has been that in these cases the companies that own and operate the ports have different perspectives on accountability, publicly disclosed information, and, thus, transparency. Taking as an example, the two biggest U.K ports-Felixstowe and Southampton-would have been included in the study; yet, when searching the website of these ports it was realised that the level of transparency, as defined in our study, is in both cases minimal; both ports disclose less information than any of the 87 ports examined in the study. Expanding research to the study of fully privatized ports and comparing the findings with the rest of the ports where the public sector maintains a direct interest and/or involvement in their governance could be an additional path to follow.

The detailed six research streams hopefully provide topics for researchers interested in this issue, and in port performance improvement through governance reform. Perhaps the greatest value of this research resides in its ability to question what sort of transparency is created, for whom and by whom. Does transparency in ports go beyond being contested governnance issues that masquerade as an administrative tool in an age of continuing interest in port governance reform?

Acknowledgements

Not applicable.

Authors' contributions

The four authors have equally contributed to all stages of the research.

Authors' information

Mary R. Brooks is Professor Emeritus at Dalhousie University, Canada and Laureate, Onassis Prize in Shipping 2018. Geraldine Knatz is Professor of the Practice of Policy and Engineering at USC Sol Price School of Public Policy and USC Viterbi School of Engineering, University of Southern California, U.S.A.

Athanasios A. Pallis is Professor of Management of Ports and Shipping, at the Department of Port Management and Shipping, National and Kapodistrian University of Athens, Greece.

Gordon Wilmsmeier is Professor, Kühne Professorial Chair in Logistics at the School of Management, Universidad de Los Andes, Colombia and Associate Professor for Shipping and Global Logistics, Kühne Logistics University (KLU), Germany.

Funding

This research did not receive any specific grant from funding agencies in the public, commercial, or not-for-profit sectors.

Availability of data and material

Not applicable.

\section{Declarations}

Competing interests

The authors declare that they have no competing interests.

\section{Author details}

${ }^{1}$ Dalhousie University, Halifax, Canada. ${ }^{2}$ University of Southern California, Los Angeles, USA. ${ }^{3}$ Department of Port Management and Shipping, National and Kapodistrian University of Athens, Evripou Campus, 34400 Athens, Greece. ${ }^{4}$ Universidad de Los Andes, Bogotá, Colombia. ${ }^{5}$ Kühne Logistics University (KLU), Hamburg, Germany. 
Received: 8 November 2021 Accepted: 20 December 2021

Published online: 04 January 2022

\section{References}

Albu OB, Flyverboom M (2016) Organizational transparency: conceptualizations, conditions, and consequences. Bus Soc 58(2):268-297

Baena P, Vieyra JC (2011) Access to information and targeted transparency policies (IDB Technical Note IDB-TN-321). InterAmerican Development Bank, Washington, DC

Berglund T (2014) Corporate governance and optimal transparency. In: Forssbaeck J, Oxelheim L (eds) The Oxford handbook of economic and institutional transparency. Oxford University Press, Oxford, pp 359-370

Bernstein ES (2012) The transparency paradox: a role for privacy in organizational learning and operational control. Adm Sci Q 57(2):181-216

Brooks MR (2017) A new direction or stay the course? Canada's port-specific challenges resulting from the port reform program of the 1990s. Res Transp Bus Manag 22:161-170

Brooks MR, Cullinane K (2006) Devolution, port governance and port performance. Elsevier, Amsterdam

Brooks MR, Pallis AA (2008) Assessing port governance models: process and performance components. Marit Policy Manag 35(4):411-432

Brooks MR, Pallis AA (2012) Port governance. In: Talley WK (ed) Maritime economics: a Blackwell companion. Wiley-Blackwell, Walden, pp 232-267

Brooks MR, Cullinane KPB, Pallis AA (2017) Revisiting port governance and port reform: a multi-country examination. Res Transp Bus Manag 22:1-10

Brooks MR, Knatz G, Pallis AA, Wilmsmeier G (2021) Visibility and verifiability in port governance transparency: exploring stakeholders expectations. WMU J Marit Affairs. https://doi.org/10.1007/s13437-021-00250-2

Brooks MR, Knatz G, Pallis AA, Wilmsmeier G (2020) Transparency in governance: seaport practices. PortReport No 5. https://www.porteconomics.eu/mdocs-posts/portreport-no-5-2020-7-brooks-et-al

Brown E, Cloke J (2004) Neoliberal reform, governance and corruption in the south: assessing the international anticorruption crusade. Antipode 36(2):272-294

Bushman RM, Piotroski JD, Smith AJ (2004) What determines corporate transparency? J Acc Res 42(2):207-252

Christensen LT, Cornelissen J (2015) Organizational transparency as myth and metaphor. Eur J Soc Theory 18(2):132-149

Craft S, Heim K (2008) Transparency in journalism: meanings, merits, and risks. In: Wilkins L, Christians CG (eds) Handbook of mass media ethics. Routledge, New York, pp 217-228

Craig C, Ngondo P, Flynn MA (2016) How firm is your digital handshake? Mission statements and transparency. Public Relat Rev 42(4):692-694

Eijffinger SCW, Geraats PM (2006) How transparent are central banks?'. Eur J Polit Econ 22(1):1-21

Fenster M (2015) Transparency in search of a theory. Eur J Soc Theory 18(2):150-167

Finel BI, Lord KM (1999) The surprising logic of transparency. Int Stud Q 43(2):325-339

Gupta A (2008) Transparency under scrutiny: information disclosure in global environmental governance. Glob Environ Polit 8(2):1-7

Heald D (2006) Varieties of transparency. In: Hood C, Heald D (eds) Transparency: the key to better governance? Oxford University Press, Oxford, pp 23-45

Hess D (2012) Combating corruption through corporate transparency: using enforcement discretion to improve disclosure. Minn J Int Law 21(1):42-74

Hofstede G (1980) Culture's consequences: international differences in work-related values, 1st edn. Sage Publications, Beverly Hills

Hood C (2006) Transparency in historical perspective. In: Hood C, Heald D (eds) Transparency: the key to better governance? Oxford University Press, Oxford, pp 3-23

Hood C (2007) What happens when transparency meets blame-avoidance? Publ Manag Rev 9(2):191-210

Hultman J, Axelsson B (2007) Towards a typology of transparency for marketing management research. Ind Mark Manag 36(5):627-635

Knatz G (2017) How competition is driving change in port governance, strategic decision-making and government policy in the United States. Res Transp Bus Manag 22:67-77

Kundeliene K, Leitoniene S (2015) Business information transparency: causes and evaluation possibilities. In: ProcediaSocial and behavioral sciences, 20th international scientific conference economics and management (ICEM-2015), pp 340-344

Menozzi A, Vannoni D (2014) Political connections in boards of directors. Netw Ind Q 16(3):8-10

Michener G, Bersch K (2013) Identifying transparency. Inf Polity 18(3):233-242

Michener G, Marrey Moncau LF, Velasco R (2014) Estado Brasileiro e Transparência Avaliando a aplicação da Lei de Acesso à Informação. https://bibliotecadigital.fgv.br/dspace/bitstream/handle/10438/17936/report_the_brazilian_state_ and_transparency___portuguese.pdf

Molina E, Vieyra J (2012) Transparency as a public policy tool. In: Dassen N, Vieyra J (eds) Open government and targeted transparency: trends and challenges for Latin America and the Caribbean. Inter-American Development Bank, Washington, DC

Ng KYA, Pallis AA (2010) Port governance reforms in diversified institutional frameworks: generic solutions, implementation asymmetries. Environ Plan A 42(9):2147-2167

Notteboom T, De Langen PW, Jacobs W (2013) Institutional plasticity and path dependence in seaports: interactions between institutions, port governance reforms and port authority routines. J Transp Geogr 27:26-35

Notteboom T, Parola F, Satta G, Penco L (2015) Disclosure as a tool in stakeholder relations management: a longitudinal study on the Port of Rotterdam. Int J Logist Res Appl 18(3):228-250 
Notteboom T, Pallis AA, Rodrigue J-P (2021) Port economics, management and policies. Routledge, New York O'Brien P, Pike A, Tomaney J (2019) Governing the 'ungovernable'? Financialisation and the governance of transport infrastructure in the London 'global city-region". Prog Plan. https://doi.org/10.1016/j.progress.2018.02.001

Parola F, Satta G, Penco L, Profumo G (2013) Emerging port authority communication strategies: assessing the determinants of disclosure in the annual report. Res Transp Bus Manag 8:134-147

Santos S, Rodrigues LL, Branco CM (2016) Online sustainability communication practices of European seaports. J Clean Prod 112:2935-2942

Schnackenberg AK, Tomlinson EC (2016) Organizational transparency: a new perspective on managing trust in organization-stakeholder relationships. J Manag 42(7):1784-1810

Transparency International (2019) Corruption Perceptions Index 2018. Retrieved February 6, 2019. https://www.trans parency.org/cpi2018

Ubbels B (2005) Institutional barriers to efficient policy intervention in the European port sector. IATSS Res 29(2):41-49 Valentinov V, Verschraegen G, Assche K (2019) The limits of transparency: a systems theory view. Syst Res Behav Sci 36(3):289-300

Verhoeven P, Vanoutrive T (2012) A quantitative analysis of European port governance. Marit Econ Logist 14(2):178-203 Wehmeier S, Raaz O (2012) Transparency matters: the concept of organizational transparency in the academic discourse. Public Relat Inq 1(3):337-366

Williams CC (2005) Trust diffusion: the effect of interpersonal trust on structure, function, and organizational transparency. Bus Soc 44(3):357-368

\section{Publisher's Note}

Springer Nature remains neutral with regard to jurisdictional claims in published maps and institutional affiliations.

\section{Submit your manuscript to a SpringerOpen ${ }^{\circ}$ journal and benefit from:}

- Convenient online submission

Rigorous peer review

Open access: articles freely available online

- High visibility within the field

Retaining the copyright to your article

Submit your next manuscript at $\boldsymbol{\Delta}$ springeropen.com 